Journal of Epidemiology and Public Health (2016), 1(3): 195-202

https://doi.org/10.26911/jepublichealth.2016.01.03.06

\title{
The Association Between Maternal Education, Family Income, House Sanitation, and the Incidence of Acute Respiratory Tract Infection in Children Under Five
}

\author{
Anita Sri Sulistyo'), Didik Tamtomo²), Ambar Mudigdo²) \\ 1) District Health Office Wonogiri, Central Java \\ 2) Faculty of Medicine, Universitas Sebelas Maret, Surakarta
}

\begin{abstract}
Background: It was estimated that the incidence of Acute Respiratory Tract Infection (ARTI), including pneumonia, was $\mathbf{1 0 - 2 0 \%}$ in children under five in Indonesia. Therefore ARTI in children under five is a public health important that calls for control and prevention. The purpose of this study was to determine the association between maternal education, family income, house sanitation, and the incidence of ARTI in children under five.

Subjects and Method: This was an analytic observational study with case control design. This study was conducted in Wonogiri 1 and Kismantoro Health Centers, Wonogiri, Central Java, from September to October, 2016. A total sample of 200 children under five were selected for this study by fixed disease sampling, consisting of 100 children with ARTI and 100 children without ARTI. The dependent variable was pneumonia. The independent variables were maternal education, family income, house component, and house sanitation. The data were collected by a set of questionnaire, checklist, and medical record at the health centers. The data were analyzed by multiple logistic regression.

Results: Maternal education $\geq$ senior high school (OR=0.09; 95\% CI=0.03 to $0.22 ; \mathrm{p}<0.001$ ), house component meeting the required standard $(\mathrm{OR}=0.27 ; 95 \% \mathrm{CI}=0.13$ to $0.57 ; \mathrm{p}<0.001)$, and good house sanitation $(\mathrm{OR}=0.15 ; 95 \% \mathrm{CI}=0.06$ to $0.38 ; \mathrm{p}<0.001)$ were associated with decreased risk of pneumonia in children under five, and they were statistically significant. The association between family income and the risk of pneumonia was not statistically significant (OR=0.87; $95 \%$ $\mathrm{CI}=0.42$ to $1.79 ; \mathrm{p}=0.703)$.

Conclusion: Maternal education $\geq$ senior high school, house component meeting the required standard, and good house sanitation are associated with decreased risk of pneumonia in children under five.
\end{abstract}

Keywords: maternal education, family income, house sanitation, pneumonia, children under five

Correspondence:

Anita Sri Sulistyo. District Health Office Wonogiri, Central Java.

Email: anitasrisulistyowati@yahoo.com

BACKGROUND

ARTI is often referred to as "the main killer". ARTI cases are one of the main causes of patient visits to health facilities, which is $40 \%$ to $60 \%$ of all visits to Puskesmas and $15 \%$ to $30 \%$ of all outpatient visits and hospitalizations. It is estimated that deaths from ARTI, especially pneumonia, reach 5 cases among 1,000 children under five. This means that ARTI causes 150,000 chil- dren under five to die each year, or 12,500 victims per month, or 416 cases per day, or 17 children per hour or an infant every 5 minutes (Ministry of Health, 2015).

ARTI is still one of the main public health problems, especially in infants (o-11 months) and toddlers (1-4 years) in Indonesia. It is estimated that the incidence of AR$\mathrm{TI}$ in infants in Indonesia is $10-20 \%$. Based on Household Health Survey results, ARTI 
in 1986 was ranked 4th (12.4\%) as a cause of infant mortality. Whereas in 1992 and 1995, this was the main cause of infant mortality, whic was $37.7 \%$ and $33.5 \%$. The results of the Household Health Survey in 1998 also showed that ARTI was the main cause of death in infants (36\%). The results of the Household Health Survey in 2001 showed that the high prevalence of ARTI was $39 \%$ in infants and $42 \%$ in children under five (Ministry of Health, 2001).

Based on the results of the 2001 National Health Survey, it was found that respiratory infections (Pneumonia) became the highest cause of under-five mortality (22.8\%) and the second cause of infant mortality after perinatal disorders. The highest prevalence is found in infants aged 6-11 months. Not only toddlers, respiratory infections were the second most common cause of death with a proportion of $12.7 \%$ (Ministry of Health, 2001). The 2005 mortality survey placed ARTI as the biggest cause of death in Indonesia with a percentage of $22.30 \%$ of all deaths (Susilowati, 2010). Evidence that ARTI was the main cause of death was the increasing number of ARTI patients.

Based on Ministry of Health (2005), 20-30\% of deaths are caused by ARTI. Furthermore, based on the results of Basic Health Research report in 2007, the highest ARTI prevalence occurred in two-year-old babies (> 35\%). ARTI tends to occur higher in groups with low levels of education and household expenditure.

Ministry of Health data shows that ARTI in Indonesia throughout 2007 to 2011 experienced an upward trend. In 2007 the number of ARTI cases was categorized as 7,281,411 non-pneumonia coughs cases and 765,333 cases of pneumonia, then in 2011 it reached 18,790,481 million cases of nonpneumonia coughs and 756,577 pneumonia.
Based on the Monthly Morbidity Report, the incidence of ARTI was 6,900 and the prevalence of ARTI was 7,720 during December 2015 from 34 health centers that reported morbidity data in Wonogiri Regency (Wonogiri Health Office, 2015). Factors causing ARTI are bacteria such as Streptococcus pyogenes, Staphylococcus aureus, and viruses such as Microvirus, Adenovirus. The bacteria emerge from dirty environments, air that tends to change and also air pollution that rises.

The purpose of this study was to analyze the relationship of maternal education, family income, home components and home sanitation with the incidence of ARTI in infants in Wonogiri Regency with logistic regression analysis approach.

\section{SUBJECT AND METHOD \\ 1. Design Study \\ This was an analytic observational study with case control design. This study was conducted in Wonogiri 1 and Kismantoro Health Centers, Wonogiri, Central Java, from September to October, 2016.}

\section{Population and Sampling}

The target population of the study were childen under five in Banjarnegara Regency region. The source population in this study were childen under five. A sample of 200 study subjects were selected by fix disease sampling, with a ratio of $1: 1$ between diseased (case) and non-diseased (control) groups.

\section{Study variables}

The variables of the study were maternal education, family income, house component, house sanitation and ARTI in children under five.

\section{Study Instrument}

The data were collected by a set of questionnaire, checklist, and medical records. 
Journal of Epidemiology and Public Health (2016), 1(3): 195-202

https://doi.org/10.26911/jepublichealth.2016.01.03.06

\section{Data Analysis}

Logistic regression analysis was performed with SPSS.

\section{RESULT}

1. Characteristics of study subjects

Table 1 showed that of 200 study subjects had different distributions. Description of study variables was explained based on characteristics, frequency and percentage.

Comparison of study subjects who had ARTI and not ARTI was balanced, 50:50. Most of the study subjects had primary education (elementary, junior high, high school) (69.5\%), family income was less than Rp1,252,000 (75\%), and poor home sanitation (74\%).

Table 1. Description of study variables

\begin{tabular}{lcc}
\hline Variable & n & \% \\
\hline Children Under Five ARTI Status & & \\
Non ARTI & 100 & $50 \%$ \\
ARTI & 100 & $50 \%$ \\
Maternal Education & 61 & $30.5 \%$ \\
High level of education (Diploma, Bachelor) & 139 & $69.5 \%$ \\
Low level of education (elementary, junior high, high school) & & \\
Family Income & 92 & $25 \%$ \\
$\geq$ Rp 1.252.000 & 108 & $75 \%$ \\
< Rp 1.252.000 & & \\
Meuse Components & 101 & $50.5 \%$ \\
Not meeting the required standard (<80\%) & 99 & $49.5 \%$ \\
Home Sanitation & & $26 \%$ \\
Meeting the required standard (80-100\%) & 52 & $74 \%$ \\
Not meeting the required standard $(<80 \%)$ & 148 & \\
\hline
\end{tabular}

\section{Bivariate Analysis}

The variables in this study were the status of ARTI in children under five, maternal

Table 2. Results of bivariate analysis

\begin{tabular}{lcccc}
\hline \multicolumn{1}{c}{ Independent Variable } & \multirow{2}{*}{ OR } & \multicolumn{2}{c}{$\mathbf{9 5 \%}$ CI } & \multirow{2}{*}{ p } \\
\cline { 3 - 4 } & & Upper limit & Lower limit & \\
\hline Low level of education & 0.06 & 0.27 & 0.15 & $<0.001$ \\
Low family income & 0.92 & 1.61 & 0.53 & 0.77 \\
Poor house components & 0.19 & 0.35 & 0.10 & $<0.001$ \\
Home sanitation & 0.11 & 0.25 & 0.05 & $<0.001$ \\
\hline
\end{tabular}

\section{Multiple Logistic Regression}

Multivariate analysis described the influence of maternal education, family income, home components, home sanitation, and ARTI in children under five.

\section{Relationship of Education with the Occurrence of ARTI in Children Under Five}

The results showed that there was a relationship between educational and the risk education, income, home components and home sanitation. The method used was the chi-square test. of children under five experiencing ARTI and it was statistically significant. Children under five who lived with highly educated mothers had a lower risk of developing ARTI than those who lived with low educated mothers. This is in line with the study of Sukamawa (2006) that maternal education was directly related to the incidence of ARTI in children under five. 
Table 3. The results of logistic regression analysis of the relationship between the maternal education, income, housing components and sanitary home with ARTI in children under five

\begin{tabular}{lcccc}
\hline \multirow{2}{*}{ Independent Variable } & \multirow{2}{*}{ OR } & \multicolumn{2}{c}{ 95\% CI } & \multirow{2}{*}{ p } \\
\cline { 3 - 4 } & & Lower Limit & Upper Limit & \\
\hline Education $\geq$ High school & 0.09 & 0.03 & 0.22 & $<0.001$ \\
Income $\geq$ Rp 1,252,000 & 0.87 & 0.42 & 1.79 & 0.703 \\
House components that meet the & 0.27 & 0.13 & 0.57 & $<0.001$ \\
required standard & & & 0.38 & $<0.001$ \\
$\begin{array}{l}\text { Good house sanitation } \\
\text { N observation = 200 }\end{array}$ & 0.15 & 0.06 & & \\
$\begin{array}{l}\text { Nagelkerke R-Square = 49.5\% } \\
\text { p=0.052 }\end{array}$ & & & & \\
\hline
\end{tabular}

Tupasi's study (1988) showed that low education and socio-economic levels or low family income have a close relationship with public health. A study in the Philippines has proven that low education and socioeconomic parents will increase the risk of ARTI in children younger than 1 year.

A person's knowledge is the result of education that is not only obtained from formal education. Non-formal education can also increase public knowledge. A person's background can influence attitudes and behavior based on his knowledge. According to Sukarni (1994) in Azhar's (2013) study, education can help facilitate communication and influence the process of giving and receiving information about health so it can be easily accepted by family members. According to Bloom (1956) (in the Taxonomy of Education Objective) knowledge is the ability to recognize and remember definitions, and is the initial factor of an expected and generally positive behavior.

Health education for prevention of ARTI in children under five, is one of the efforts to prevent ARTI in children under five. Health education is essentially an activity or effort to convey health messages to people, groups or individuals so that they can obtain better knowledge about health. Information obtained from both formal and non-formal education can provide immediate impact so as to produce change or in- crease knowledge. According to Azwar (2002), factors such as maternal education, maternal age and maternal knowledge are as extrinsic factors that influence the incidence of ARTI in children under five.

\section{Relationship of family income with the occurrence of ARTI in children}

The results showed that there was a relationship between family income and risk of children under five experiencing ARTI and it was not statistically significant. Children under five who lived with high-income families had a lower risk of developing ARTI than those who lived with low-income families. This was in line with Sukamawa's study (2006), which stated that family income was directly related to the incidence of AR$\mathrm{TI}$ in children under five.

In the study of Anwar and Ika (2014), stated that the risk of ARTI in children under five is higher in households with a low economic level, compared to those living at high economic levels with a value of $\mathrm{OR}=$ 1.19. The study conducted by Kosai et al., (2015) also stated that there is a significant relationship between socioeconomic status and an increased risk of ARTI in children under five. Based on Ministry of Health (2009), it was found that $20-30 \%$ of deaths are caused by ARTI. Furthermore, based on the results of the Basic Health Research report in 2007, the highest ARTI prevalence occurre in two-year-old babies $(\geq 35 \%)$, 
Journal of Epidemiology and Public Health (2016), 1(3): 195-202

https://doi.org/10.26911/jepublichealth.2016.01.03.06

ARTI tends to occur higher in groups with low education and low levels of household expenditure.

Health care was comprehensive and health services were easily accessible from various walks of life, both low and high economies. The findings that occured in the study were families with high economic level tended to have high activity, and rarely paid attention to the health of children because they were usually kept in their grandmothers' care when their parents worked, so that child health monitoring had not been focused.

\section{Relationship of home components with ARTI occurrences in children under five}

There was a relationship between the house components and the risk of children under five experiencing ARTI and it was statistically significant. Children under five who lived in an environment with home components fulfilling the requirement had a lower risk of developing ARTI than those who lived in the neighborhood with home components that do not meet the requirements. Socioeconomic conditions is one of the elements of the environment related to the incidence of ARTI in children under five. The residential house sanitation requirements include building materials, components and equipment of home space, lighting, air quality, ventilation, availability of water and food storage facilities and density of space occupancy sleep (Keman, 2005).

Ventilation is the process of providing fresh air and dirty air expenditure naturally or mechanically (Sukamawa, 2006). Ventilation in addition to functioning as an air exchange hole can also function as an entry hole for sunlight into the room. Lack of fresh air entering the room and high humidity can cause an increased risk of ARTI occurrence. The installation of home ventilation is one of the efforts to prevent the occurrence of ARTI (Mukono, 2009).

Spacious standard room to sleep according to the Indonesian Minister of Health Decree No.829/Menkes/SK/VII/1999 is at least $8 \mathrm{~m} 2$. It is not recommended to be used by more than two people sleeping in one bedroom, except for children under five years old (Decree of the Minister of Health of the Republic of Indonesia 829/1999). Excessive occupancy density facilitates transmission of respiratory infections, tuberculosis, meningitis and intestinal parasites from one person to another (Ministry of Health, 2005). Home cleanliness is one of the factors that influence the health of children under five.

The measurement of children under five's room humidity using a hygrometer is based on Republic of Indonesia regulation No. 1077/MENKES/PER/V/2011. Concerning the humidity requirements of a house that is $40-60 \% \mathrm{Rh}$. Houses with too high or low humidity become conditions where microorganisms can grow. According to $\mathrm{Mu}-$ hedir (2002) humidity in the house can be influenced by poor house construction, poor ventilation and minimal lighting. Humidity can be affected by several things such as a home environment that does not meet the requirements or by the weather. Humidity during the rainy season will increase. However, if the home conditions are good such as sunlight can enter the room, there is no puddle of water, adequate ventilation, it can retain moisture in the house.

\section{Relationship of home sanitation with ARTI occurrences in children under five}

There was a relationship between home sanitation and the risk of a children under five experiencing ARTI and it was statistically significant. Children under five who lived in an environment with good home sanitation had a lower risk of developing 
ARTI than those who lived in an environment with poor home sanitation. The results of this study were in accordance with a study conducted by Pribadi (2008) which explained that the physical environment of a house that did not meet health requirements could support the transmission of diseases and health problems.

Physical environmental risk factors in this study had OR 7.4 times increasing the risk of ARTI occurrence. The Government has established regulations concerning housing health requirements, namely the Decree of the Minister of Health Number 829/MENKES/SK/VII/1999 concerning Housing Health Requirements.

Based on Azhar and Perwitasari's (2013) study, the physical condition of houses that do not meet health requirements and fuel use behavior can increase the risk of diseases such as $\mathrm{TB}$, cataracts and ARTI. The proportion of houses in Indonesia that meet the requirements of a healthy house is still low at $24.9 \%$. According to Ahmadi (2005), environmental factors (density, floor of the house, ventilation, temperature and others) are risk factors that contribute to the onset of lung disease, in addition to population factors (gender, age, nutritional status and socioeconomic status). Similarly, physical sanitation of the house contributes to the health status of its inhabitants.

The results obtained were not in line with Siswanto's (2006) study which stated that aspects of humidity, occupancy density and home lighting were not significantly associated with the incidence of lung disease. A study in Brazil concluded that there was no correlation between the condition of the house and the incidence of ARTI in children under five. While the study of Fatimah (2008) showed a relationship between the incidence of lung disease with ro- om humidity, type of wall, ventilation and lighting.

Good home sanitation has an indicator of a healthy home environment assessment, such as ventilation conditions, floor type, wall type, roof type, lighting and occupancy density. Greater respiratory tract transmission occurs because the number of germs is more than the air exchanged, so the creation of ventilation in reducing the occurrence of air pollution in the home and the outside environment can work well (AHPHA - American Public Health Association). The dusty house floor condition is one form of indoor air pollution. Dust in the air can be attached to the lower respiratory tract so that the lung elasticity decreases and causes children under five to experience shortness of breath when inhaled (Padmonobo, 2015).

The conclusion of this study is that there is a relationship between maternal education, family income, home components and home sanitation with the incidence of upper respiratory tract infection (ARTI) in children under five.

\section{REFERENCE}

$\overline{\text { Anwar A, Ika (2014). Pneumonia pada anak }}$ balita di Indonesia. Jurnal Kesehatan Masyarakat Nasional, 8(8).

Azhar K, Perwitasari D (2013). Kondisi Fisik Rumah dan Perilaku dengan Prevalensi Paru di Provinsi DKI Jakarta, Banten dan Sulawesi Utara. Media Litbangkes 23(4).

Fatimah S (2008). Faktor kesehatan lingkungan rumah yang berhubungan dengan penyakit paru di Kabupaten Cilacap. Fakultas Kesehatan Masyarakat Universitas Diponegoro.

Kosai H, Tamaki R, Saito M, Tohma K, Alday PP, Tan AG, Inobaya MT (2015). Incidence and risk factors of childhood pneumonia-like episodes in Bili- 
Journal of Epidemiology and Public Health (2016), 1(3): 195-202

https://doi.org/10.26911/jepublichealth.2016.01.03.06

ran Island, Philippines. A Community-Based Study. Plos One 10(5).

Ministry of Health (2015). Laporan riset kesehatan dasar. Jakarta: Badan Penelitian dan Pengembangan Kesehatan Kementerian Kesehatan RI.

Mnistry of Health (2001). Pedoman pemberantasan penyakit infeksi saluran pernapasan akut untuk penanggulangan pneumonia pada balita. Ditjen PPMPLP, Jakarta.

Muhedir (2002). Hubungan faktor-faktor lingkungan rumah dengan kejadian penyakit ISPA pada anak balita di Kecamatan Jambi Selatan. Tesis. FKM UI. Depok.

Mukono HJ (2009). Prinsip Dasar Kesehatan Lingkungan. Surabaya: Airlangga University Press.

Padmonobo H, Setiani O, Joko T (2015). Hubungan faktor-faktor lingkungan fisik rumah dengan kejadian pneumonia pada balita di wilayah kerja Puskesmas Ajibarang Kabupaten Brebes. Jurnal Lingkungan Indonesia 11(2).
Pribadi S (2008). Faktor-faktor lingkungan fisik rumah dan perilaku yang berhubungan dengan kejadian pneumonia pada balita di Kabupaten Pontianak. Jurnal Kesehatan Lingkungan. Universitas Diponegoro.

Sukamawa (2006). Determinan sanitasi rumah dan sosial ekonomi keluarga terhadap kejadian ISPA pada anak balita serta manjemen penanggulangannya di Puskesmas. Jurnal Kesehatan Lingkungan UNAIR, 3(1).

Susilowati (2010). Hubungan rumah tangga sehat dengan kejadian pneumonia pada balita di Kabupaten Trenggalek. Jurnal Kesehatan Masyarakat Universitas Sebelas Maret.

WHO (2007). Pencegahan dan Pengendalian ISPA di Fasilitas Pelayanan Kesehatan. Retrivied from http://www.who.int/csr/resources/publications/ampandemicbahasa.pdf. $5 \mathrm{Fe}-$ bruary 2016.

Wonogiri Health Office (2015). Laporan Bulanan Kesakitan (LB1). 